Medical Virology 8 
A Continuation Order Plan is available for this series. A continuation order will bring delivery of each new volume immediately upon publication. Volumes are billed only upon actual shipment. For further information please contact the publisher. Plenum began publication of volumes in this series effective with Volume 8. 


\section{Medical Virology 8}

Edited by

Luis M. de la Maza

and

Ellena M. Peterson

University of California, Irvine Medical Center

Orange, California 
Library of Congress Card Catalog Number 89-657524

ISBN 978-1-4899-0893-3 ISBN 978-1-4899-0891-9 (eBook)

DOI 10.1007/978-1-4899-0891-9

Proceedings of the 1988 International Symposium on Medical Virology, held September 22-24, 1988, in San Francisco, California

(C) 1989 Springer Science+Business Media New York

Originally published by Plenum Press, New York in 1989

Softcover reprint of the hardcover 1st edition 1989

All rights reserved

No part of this book may be reproduced, stored in a retrieval system, or transmitted in any form or by any means, electronic, mechanical, photocopying, microfilming, recording, or otherwise, without written permission from the Publisher 


\section{FOREWORD}

No other area of biology has grown as fast and become as relevant over the last decade as virology. It is with no little amount of amazement, that the more we learn about fundamental biological questions and mechanisms of diseases, the more obvious it becomes that viruses permeate all facets of our lives. While on one hand viruses are known to cause acute and chronic, mild and fatal, focal and generalized diseases, on the other hand, they are used as tools for gaining an understanding of the structure and function of higher organisms, and as vehicles for carrying protective or curative therapies. The wide scope of approaches to different biological and medical virological questions was well represented by the speakers that participated in this year's symposium. While the epidemic by the human immunodeficiency virus type 1 continues to spread without hope for much relief in sight, intriguing questions and answers in the area of diagnostics, clinical manifestations and therapeutical approaches to viral infections are unveiled daily. Let us hope, that with the increasing awareness by our society of the role played by viruses, not only as causative agents of diseases, but also as models for better understanding basic biological principles, more efforts and resources are placed into their study. 


\section{ACKNOWLEDGEMENTS}

To organize an international meeting is a task that requires the efforts of many individuals, and thus it would be very difficult to recognize all those that have contributed to this year's undertaking. We want, however, to at least name those individuals that in a most unselfish manner, put forth the time and effort to make this symposium a reality. Our thanks go to all the speakers for their excellent lectures and the chapters that they contribute for this book, and to Drs. Thomas C. Cesario and Edwin E. Lennette for chairing the sessions. We want to acknowledge also the participants for their willingness to share their knowledge and their questions and by so doing making the meeting a stimulating intellectual experience.

Throughout the year the staff of the Division of Medical Microbiology at the University of California Irvine, provided us with continuous support and particular mention should be made of Marie Pezzlo and Sandra Aarnaes, who shared their efforts with us almost on a daily basis. The completion of these proceedings would not have been possible without the secretarial support of Penny Richardson and the assistance of Mirtha Nodal and Lillian Dalgleish in preparing the manuscripts. The Plenum Publishing $\mathrm{Co}$. helped us with their editorial support throughout this undertaking. We are particularly grateful to Melanie Yelity and Gregory Safford for their support.

We want also to express our appreciation to the following organizations that provided the financial support to make the symposium a reality:

Bayer AG/Miles, Inc.

Bethesda Research Laboratories

Bion Enterprises, LTD

Bio-Rad Laboratories

Coulter Immunology

Eastman Pharmaceuticals

Genentech, Inc.

Gull Laboratories, Inc.

Hoffman-La Roche, Inc.

Hyclone Laboratories, Inc.

Lilly Research Laboratories

Merck Sharp \& Dohme

Monsanto Company
Ortho Diagnostics Systems, Inc. Pharmacia LKB Biotechnology, Inc. The Rupp and Bowman Company Sandoz Research Institute Schering Corporation SmithKline \& French Laboratories Syva Company

Triton Biosciences, Inc. The Upjohn Company Virion (U.S.), Inc. ViroMED Laboratories, Inc. Whittaker Bioproducts Wyeth Laboratories 


\section{CONTENTS}

Newer Approaches to Perinatal Herpes Simplex Virus Testing....... 1 ANN L. WARFORD and EVAN STEINBERG

Laboratory Tests for Human T-Lymphotropic Virus Type I........ 23 DANA GALLO

The Analysis of Immunity to Specific Proteins of Herpes Simplex and Varicella Zoster Virus and Its Clinical Applications.... 41 ANN M. ARVIN, WAYNE M. SULLENDER, FRANCOIS BOUCHER, PAMELA $S$. DIAZ, PAUL A. HENSLEIGH and CHARLES G. PROBER

Hepatitis Delta Virus: Infection and Disease.............73 BONINO FERRUCCIO, BRUNETTO MAURIZIA ROSSANA, ROSINA FLORIANO and OLIVERI FILIPPO

Molecular Epidemiology of Epstein-Barr Virus obtained from Patients with the Chronic Fatigue Syndrome...........87 JAMES F. JONES, SUSAN BAKER and JOANNE STREIB

Infectious Complications of Human Retroviruses and Human Retroviruses as Infectious Complications..............105 JONATHAN W. M. GOLD

Statistical Issues in Assessing the AIDS Epidemic............121 VICTOR DE GRUTTOLA and WILLIAM BENNETT

Herpesvirus Trans-Activation of Human Immunodeficiency Virus

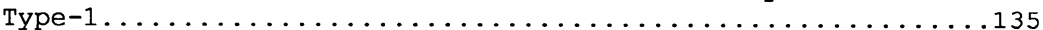
JOSEPH D. MOSCA

Regulation of Expression of HIV-1 by Viral Factors............... 151 GEORGE N. PAVLAKIS, BARBARA K. FELBER, CONNIE M. WRIGHT, CHRISTOS CLADARAS, MARGARITA HADZOPOULOU-CLADARAS and ANGELOS ATHANASSOPOULOS

Mechanism(s) of Coxsackievirus-Induced Acute Myocarditis in

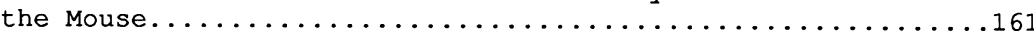
CHARLES J. GAUNTT, ELMER K. GODENY, C. WILLIAM LUTTON, HELEN M. ARIZPE, NORA M. CRAPMAN, STEVEN M. TRACY, GEORGE E. REVTYAK, ANTHONY J. VALENTE and MARIUS M. ROZEK

Adenovirus Gene Products that Affect Host Immune Mechanisms......183 PHYLLIS R. FLOMENBERG and MARSHALL S. HORWITZ

Synthetic Peptides from a Hypothetical Receptor Binding Site:

A Possible Approach to a Rhinovirus Vaccine?............213 GUDRUN WERNER and JOSEPH W. MCCRAY

Antiviral Cytotoxic T-Lymphocytes and Vaccines. STEPHEN MARTIN and BARRY T. ROUSE 
ABSTRACTS .

CONTRIBUTORS .

AUTHOR INDEX.

SUBJECT INDEX. 